Original Research

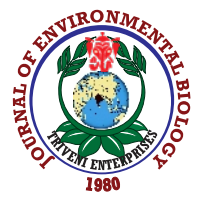

DOI : http://doi.org/10.22438/jeb/41/3/MRN-1209
Journal Home page : www.jeb.co.in $\star$ E-mail : editor@jeb.co.in Journal of Environmental Biology

p-ISSN: 0254-8704 e-ISSN: 2394-0379 CODEN: JEBIDP

\title{
Evaluation of reproductive performance in indigenous endemic ornamental fish Sahyadria denisonii using hormones under captive environment
}

\author{
N. Mahadevi ${ }^{1 *}$, S. Felix ${ }^{2}$, B. Ahilan ${ }^{1}$ and C.B.T. Rajagopalasamy ${ }^{1}$ \\ 'Department of Aquaculture, Dr. M.G.R. Fisheries College and research Institute, Ponneri-601 204, India \\ ${ }^{2}$ Tamil Nadu Dr. J. Jayalalithaa Fisheries University, Nagapattinam-611 002, India \\ *Corresponding Author Email : mahadevicof@gmail.com
}

Paper received: 15.06 .2019

Revised received: 18.09 .2019

Accepted: 05.12.2019

\section{Abstract}

Aim: The present study aimed to develop the hatchery technology for production of indigenous ornamental fish Sahyadria denisonii to ensure year round seeds and for conservation of natural resources.

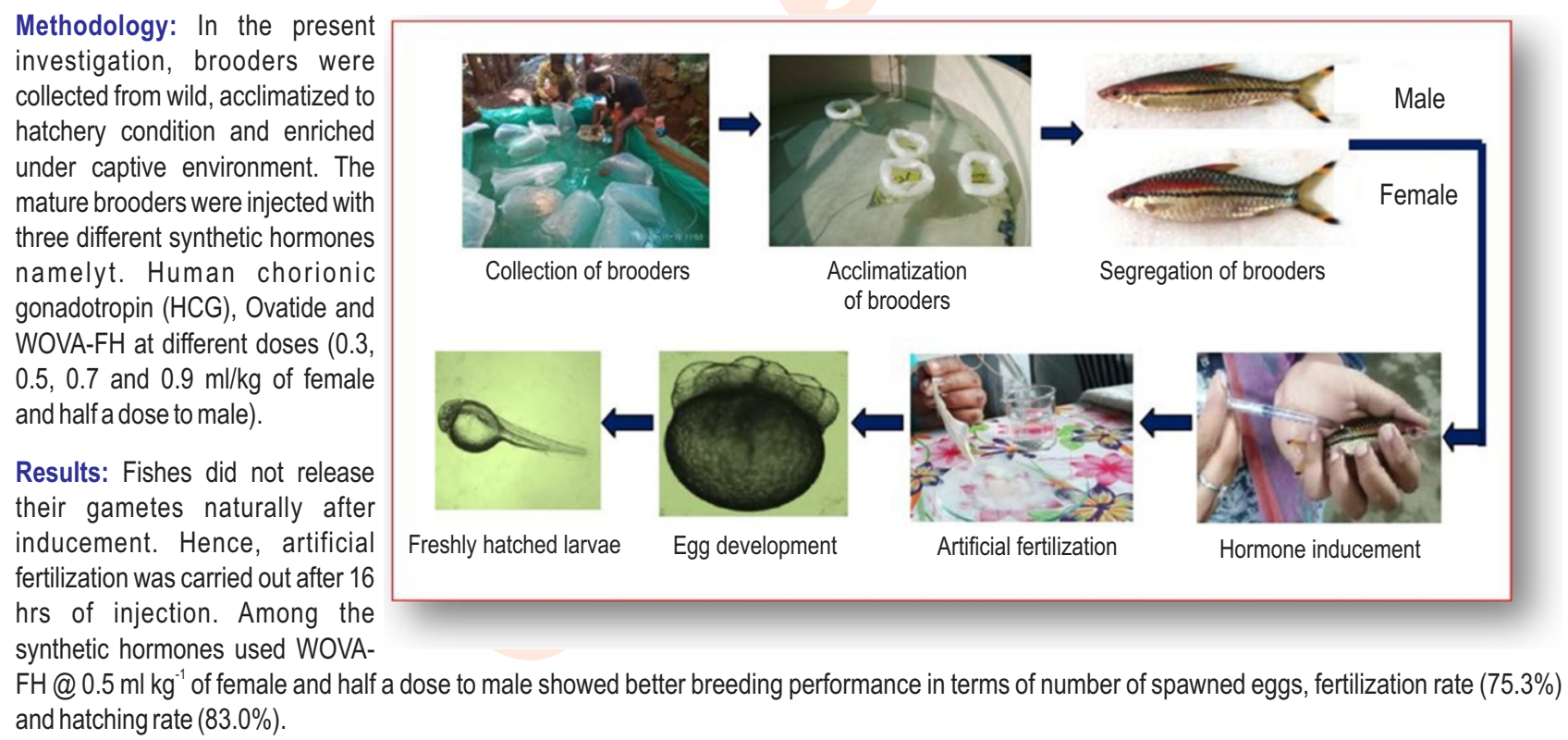
and hatching rate $(83.0 \%)$

Interpretation: Synthetic hormone WOVA-FH, human chorionic gonadotropin (HCG) and ovatide to female and male through artificial fertilization can be adopted for captive breeding of Indigenous endemic ornamental fish Sahyadria denisonii

Key words: Captive environment, Hormones, Indigenous fish, Reproductive performance, Sahyadria denisonii

How to cite : Mahadevi, N., S. Felix, B. Ahilan and C.B.T. Rajagopalasamy: Evaluation of reproductive performance in indigenous endemic ornamental fish Sahyadria denisonii using hormones under captive environment. J. Environ. Biol., 41, 549-555(2020). 


\section{Introduction}

Sahyadria denisonii (Miss Kerala) is a much sought fish in the international ornamental fish trade. S. denisonii is endemic to Western Ghats where it occurs in fragmented population in the states of Kerala and Karnataka (Prasad et al., 2008; Raghavan et al., 2010). It has been reported from the Chandhragiri Valapatnam, Karyangod, Chaliyar, Bharatapuza, Kuppam, iritti, Anjarakandipuza, Bhavani river, Chalakudi, Periyar, Manimala, Thejaswini, Achenkovil and Pampa rivers (Shaji et al., 2000; Kurup et al., 2004; Mercy, 2010). This species is characterized by a torpedo shaped body with silver scales, a horizontal red line running from the snout through eye about half way down the body and below the red line, black line that runs throughout the length of fish from snout to caudal peduncle. This slender barb has a forked tail with black or yellow spots. At maturation, they develop a distinct greenish blue marking on top of the head. The fish grows to a maximum of $15 \mathrm{~cm}$ and has longevity of 5-8 years (Menon et al., 1999). It received fame after this beautiful fish won an award in the "New Species" category at Aquarama exhibition of Singapore in 1991 (Suhair and Santhosh, 2015).

S. denisonii is an active schooling fish, thrives well in subtropical climatic condition and is more active at dawn and dusk than day time. It prefers water with a $\mathrm{pH}$ range of 6.5-7.3, hardness of $100-400 \mathrm{mgl}^{-1}$, oxygen level of $5 \mathrm{mg} \mathrm{l}^{-1}$ and above and temperature range of $18-26^{\circ} \mathrm{C}$ (Raghavan et al., 2009). S. denisonii is omnivore in nature feeding on worms, insects, crustaceans, plants material and organic debris and formulated flakes, pellets and another processed feeds. Red pigmentation can be intensified by a diet rich in carotenoids (Suhair and Santhosh, 2015). Miss Kerala (Sahyadria denisonii) constituted about $60-65 \%$ of the total live ornamental fish exported from India worth US\$ 1.54 million in the year 2008-2010. For last few decades, wild population of $S$. deniisonii has been found to decline due to various reasons. Due to over exploitation, International Union for Conservation of Nature and Natural resources (IUCN) has categorized this fish as vulnerable species in 2001, and recently it is listed under endangered because of intense exploitation, deterioration of habitat and decline in number of adult individuals due to high demand. Development of captive breeding technology is a possible way to conserve the natural biodiversity without affecting the ornamental fish trade.

Advancement in breeding technology has added a new dimension in the ornamental fish trade with species diversification and varieties being introduced (Silas et al., 2011). Induced breeding under captive condition is important tool in seed production, which ensures to get pure and required fish seed (Seema, 2013). Some attempts have been done by the researchers to induce breed the popular indigenous ornamental fishes such as Puntius titteya (Sundarabharathy et al., 2004), Puntius shalynius and Puntius sophore (Mahapatra et al., 2010), Puntius sarana (Basavaraja et al., 2014 and Udit et al., 2014), Gonoproktopterus curmuca (Padmakumar et al., 2014), Barbus gonionotus (Siddhwartha Kumar et al., 2014) and Puntius manipurensis (Motilan et al., 2014). Captive breeding technology has been developed successfully for prioritized Western Ghats ornamental fishes such as Puntius pookodensis, Puntius melanostigma, Puntius melanampyx, Garra mullya, Danio malabaricus, Chela fasciata, Nemacheilus triangularis, Nemacheilus semiarmatus and Pristolepis marginata (Mercy et al., 2009). Except for few studies on biology and breeding aspects conducted in its natural habitat (Mercy et al., 2015), captive breeding of $S$. denisonii have not yielded promising results and technology has not yet reached the farmers for commercialization. Hence, the present study was undertaken to develop the captive breeding technique for production of endemic ornamental fish, S. denisonii.

\section{Materials and Methods}

Brooders of $S$. denisonii were collected from the streams of Tejaswini River, Kasargod district of Kerala. Selected healthy brooders were packed in oxygen filled polyethylene bags and transported to Aquatic Rainbow Technology Park (ARTP), Chennai. Brood fishes (9.0-11.0 g) were stocked in Re-circulated Aquaculture system (RAS) facilitated 4 ton capacity Fibre Reinforced Plastic (FRP) tank containing water (pH: 6.8-7.0; TDS: $50-100 \mathrm{mgl}^{-1}$ ) provided with continuous aeration to mimic natural water source of Western Ghats river. Fishes were acclimatized to captive condition by feeding with plankton and small quantity of supplementary feed. After acclimatization, male and female fishes were segregated based on sexual dimorphism. Brood stock of male and female were enriched for three months with high quality protein rich (42\%) pellet feed at $5 \%$ of body weight and intermittently fed with blood worms to induce maturation. Mature brooders were selected and injected intramuscularly between the anterior region of dorsal fin and lateral line with inducing agents. Selected brooders were induced with synthetic hormones namely, Human chorionic gonadotropin (HCG), Ovatide and WOVA-FH at different doses (0.3, 0.5, 0.7 and $0.9 \mathrm{ml} \mathrm{kg}^{-1}$ b.wt. of female and half dose to male).

The experiment was designed with twelve treatments $T 1$ $\left(\mathrm{HCG}\right.$ at $\left.0.3 \mathrm{ml} \mathrm{kg}^{-1}\right), \mathrm{T} 2$ ( $\mathrm{HCG}$ at $\left.0.5 \mathrm{ml} \mathrm{kg}^{-1}\right), \mathrm{T} 3$ ( $\mathrm{HCG}$ at $0.7 \mathrm{ml} \mathrm{kg}$ ${ }^{1}$ ), T4 (HCG at $0.9 \mathrm{ml} \mathrm{kg}^{-1}$ ), T5 (Ovatide at $0.3 \mathrm{ml} \mathrm{kg}^{-1}$ ), T6 (Ovatide at $\left.0.5 \mathrm{ml} \mathrm{kg}^{-1}\right), \mathrm{T} 7$ (Ovatide at $\left.0.7 \mathrm{ml} \mathrm{kg}^{-1}\right), \mathrm{T} 8$ (Ovatide at $0.9 \mathrm{ml} \mathrm{kg}$ $\left.{ }^{1}\right)$, T9 (WOVA-FH at $0.3 \mathrm{ml} \mathrm{kg}^{-1}$ ), T10 (WOVA-FH at $0.5 \mathrm{ml} \mathrm{kg}^{-1}$ ), T11 (WOVA-FH at $0.7 \mathrm{ml} \mathrm{kg}^{-1}$ ), T12 (WOVA-FH at $0.9 \mathrm{ml} \mathrm{kg}^{-1}$ ) and control in triplicate. Females were induced with two split doses, first dose was administrated at 6.00 p.m. and second dose at 12.00 p.m. Males were induced once with half dose, while administrating the second dose to female. Induced fishes, i.e., males and females were released into the hapa fixed inside the aquarium tanks in 2:1 ratio. The fishes of control group were maintained without hormonal. S. denisonii did not release the eggs naturally in control and in the treatments, hence, artificial fertilization was carried out after 14-16 hrs upon hormonal injection. For artificial fertilization, the induced brooders were anesthetized was 2-phenoxy ethanol. Initially, the females were stripped on a clean watch glass by applying gentle pressure over 
the abdomen. Following that without much delay within $45-60 \mathrm{sec}$ males were also stripped and milt was poured over the eggs. The egg and milt collected on the watch glass was mixed thoroughly using fine fur brush. Fertilized eggs were washed with distilled water to clear the excess milt and other debris. The fertilized eggs were then transferred into the aerated glass tank. Fertilized eggs were collected and placed on the petri-dish along with water collected from hatching tank and observed under a microscope. Each developmental stage of egg and embryo (till hatching) was recorded as image with a trinocular microscope attached with a camera and a monitor display.

The efficiency of hormone-inducement was estimated based on parameters like spawned eggs, fertilization rate and hatching rate. Spawned eggs were estimated by random sampling and counting. The fertilization rate of eggs was determined by observing and counting fertilized eggs having intact nucleus of the total eggs released. Hatching rate was estimated by comparing the number of larvae released and fertilized eggs. Fertilization rate and hatching rate was calibrated.

Statistical analyses: The results were compared by analysis of variance (ANOVA) using SPSS package, VERSION 20. Duncan's Multiple Range Test was used for post-hoc comparison of mean $(P<0.05)$ between different groups. All the data presented in the text, figures and tables were expressed as mean \pm standard error. Statistical significance for the test was set at $P<0.05$.

\section{Results and Discussion}

In the present study, S. denisonii was successfully bred under captivity by adopting induced breeding technique. Control group fishes did not show positive response of breeding. Among the treatments, artificial fertilization was carried out by stripping the males and females after 14-16 hrs of inducement. Since, natural release of gametes was not observed in induced fishes, the latency period was not considered to evaluate the hormone efficiency. Among the treatments, $0.3 \mathrm{ml} \mathrm{kg}^{-1}$ body weight of female and half dose to male ( $\mathrm{T} 1, \mathrm{~T} 5$ and $\mathrm{T} 9$ ) none of the hormone treatment showed positive response to artificial fertilization.

Breeding response varies with the mode of action of the hormone which may be attributed to varied levels of dopamine activity in different fishes (Billiard et al., 1984; Peter et al., 1986) this may be the reason for the significantly varied breeding response among the hormones and doses in the present study. Significant difference $(P<0.05)$ was observed in the quantity of spawned eggs among the treatments. The interactive effect of hormone and dose revealed that combination of WOVA-FH @ $0.5 \mathrm{ml} \mathrm{kg}^{-1}$ resulted in high number of eggs, i.e., 556.66 nos $13 \mathrm{~g}^{-1}$ female. Further, T4, T8 and T12 treatments were considered poor, followed by T1, T5 and T9 among the treatments, since these treatment groups released low quantity of eggs by stripping. Similarly at low and high doses, Das et al. (2016), Sundarabarathy et al. (2004) and Motilan et al. (2014) reported poor breeding success in Osteobrama belangeri, Puntius titteya and Pethia manipurensis.

In the present investigation, it was observed that fertilization rate varied significantly $(P<0.05)$ at different doses and hormone. The interaction effect (Table 1) revealed that T10 yielded the highest fertilization rate $(75.3 \%)$ and poor fertilization was observed at T1, T5 and T9 followed by T4, T8 and T12 dose. Usually, inducement of fish at higher and lower dose causes poor fertilization that might be due to early and late inducement in brooders (Routray et al., 2001). But, in case of artificial fertilization, low fertilization at higher dose might be attributed to its dopamine activity at different doses (Das et al., 2016). The highest percent of hatching rate $(83 \%)$ was observed in T10 treatment. Similar to the present study, WOVA-FH was reported

Table 1: Breeding performance of indigenous ornamental fish S. denisonii with, different hormones and dose interaction

\begin{tabular}{lllll}
\hline Treatments & $\begin{array}{l}\text { Spawned eggs } \\
\text { (Nos/female) }\end{array}$ & $\begin{array}{l}\text { Fertilization } \\
\text { rate }(\%)\end{array}$ & $\begin{array}{l}\text { Hatching } \\
\text { rate }(\%)\end{array}$ & $\begin{array}{l}\text { Breeding } \\
\text { performance }\end{array}$ \\
\hline T1 (HCG at $0.3 \mathrm{ml}$ ) & 0.0 & 0.0 & 0.0 & Poor \\
T2 (HCG at $0.5 \mathrm{ml})$ & $240^{\mathrm{a}}$ & $47.66^{\mathrm{b}}$ & $55.00^{\mathrm{a}}$ & $\begin{array}{l}\text { Average } \\
\text { Good }\end{array}$ \\
T3 (HCG at $0.7 \mathrm{ml}$ ) & $343.33^{\mathrm{c}}$ & $58.00^{\mathrm{d}}$ & $68.66^{\mathrm{c}}$ & Average \\
T4 (HCG at $0.9 \mathrm{ml})$ & $310.0^{\mathrm{b}}$ & $41.00^{\mathrm{b}}$ & $60.333^{\mathrm{b}}$ & Poor \\
T5 (Ovatide at $0.3 \mathrm{ml})$ & 0.0 & 0.0 & 0.0 & Good \\
T6 (Ovatide at $0.5 \mathrm{ml})$ & $253^{\mathrm{a}}$ & $50.00^{\mathrm{c}}$ & $69.00^{\mathrm{c}}$ & Good \\
T7 (Ovatide at $0.7 \mathrm{ml})$ & $306.6^{\mathrm{b}}$ & $42.661^{\mathrm{b}}$ & $71.33^{\mathrm{c}}$ & Average \\
T8 (Ovatide at $0.9 \mathrm{ml})$ & $371.6^{\mathrm{c}}$ & $38.33^{\mathrm{a}}$ & $62.661^{\mathrm{b}}$ & Poor \\
T9 (WOVA-FH at $0.3 \mathrm{ml})$ & 0.0 & 0.0 & 0.0 & Better \\
T10 (WOVA-FH at $0.5 \mathrm{ml})$ & $556.6^{\mathrm{e}}$ & $75.33^{\mathrm{f}}$ & $83.00^{\mathrm{e}}$ & Good \\
T11 (WOVA-FH at $0.7 \mathrm{ml})$ & $449.3^{\mathrm{d}}$ & $64.33^{\mathrm{e}}$ & $79.33^{\mathrm{d}}$ & Poor \\
T12 (WOVA-FH at $0.9 \mathrm{ml})$ & 0.0 & 0.0 & 0.0 & - \\
SEM & 9.484 & 1.440 & 1.330 & - \\
\hline
\end{tabular}

( ${ }^{\star}$ Values with different superscript within the column differ significantly.) 


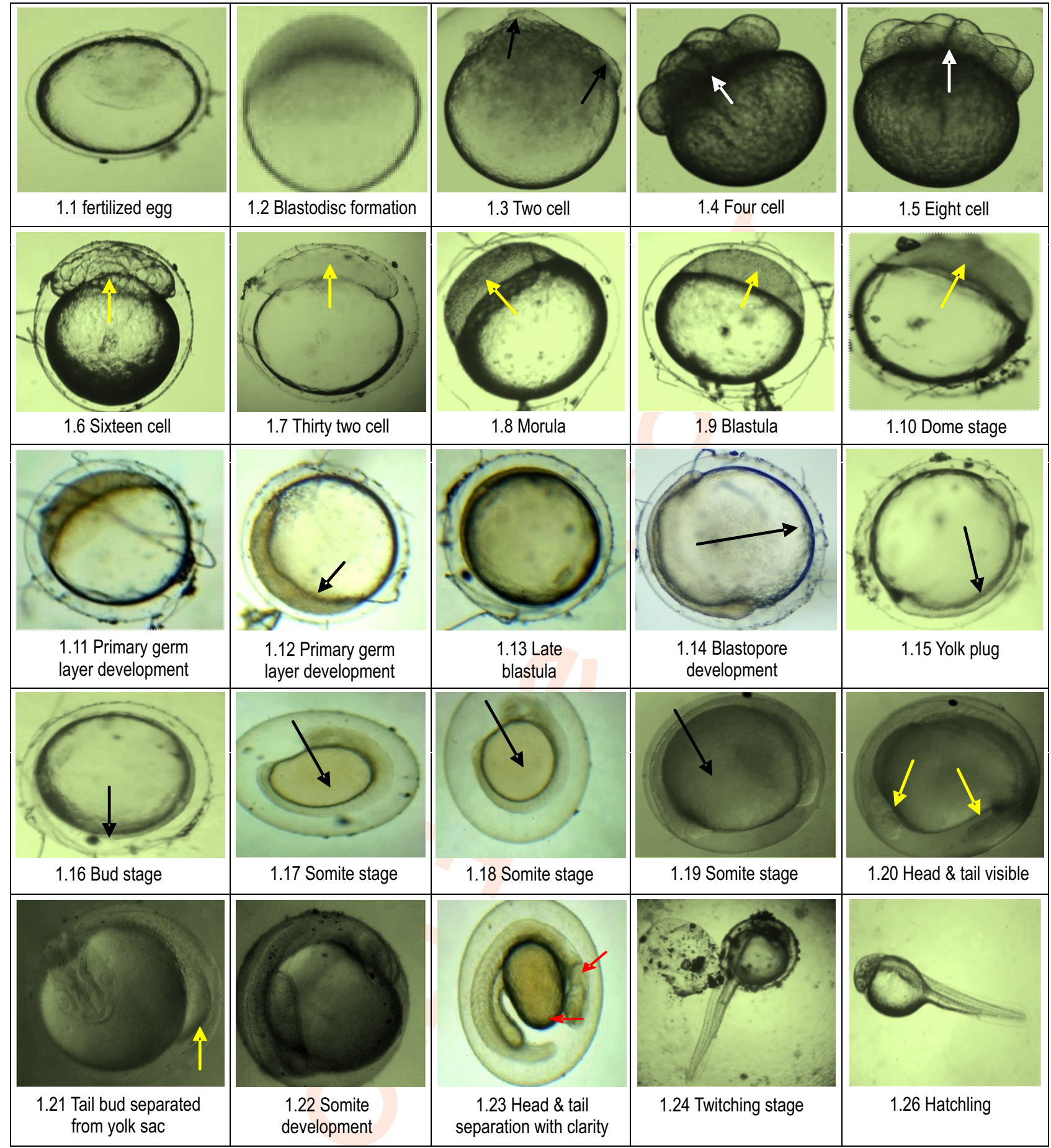

Fig. 1: Egg and embryonic developmental stages of $S$. denisonii observed under trinocular microscope. The developmental stages were observed from $0.10 \mathrm{hrs}$ (fig. 1.1) to $34.00 \mathrm{hrs}$ (fig. 1.26) till hatching.

to be an ideal hormone for inducing breeding in captivity for majority of fresh water teleosts (Sundarabarathy et al., 2004; Behera et al., 2010; Motilan et al., 2014). Higher spawning and hatching rate in Indian major carps with administration of
WOVA-FH at 0.4-0.5 ml kg for female body weight was reported by Rath et al. (2001). Likewise, Behera et al. (2010) and Motilan et al. (2014) reported the highest spawning and hatching rate in captive breeding of $O$. belangeri and $P$. manipurensis when 


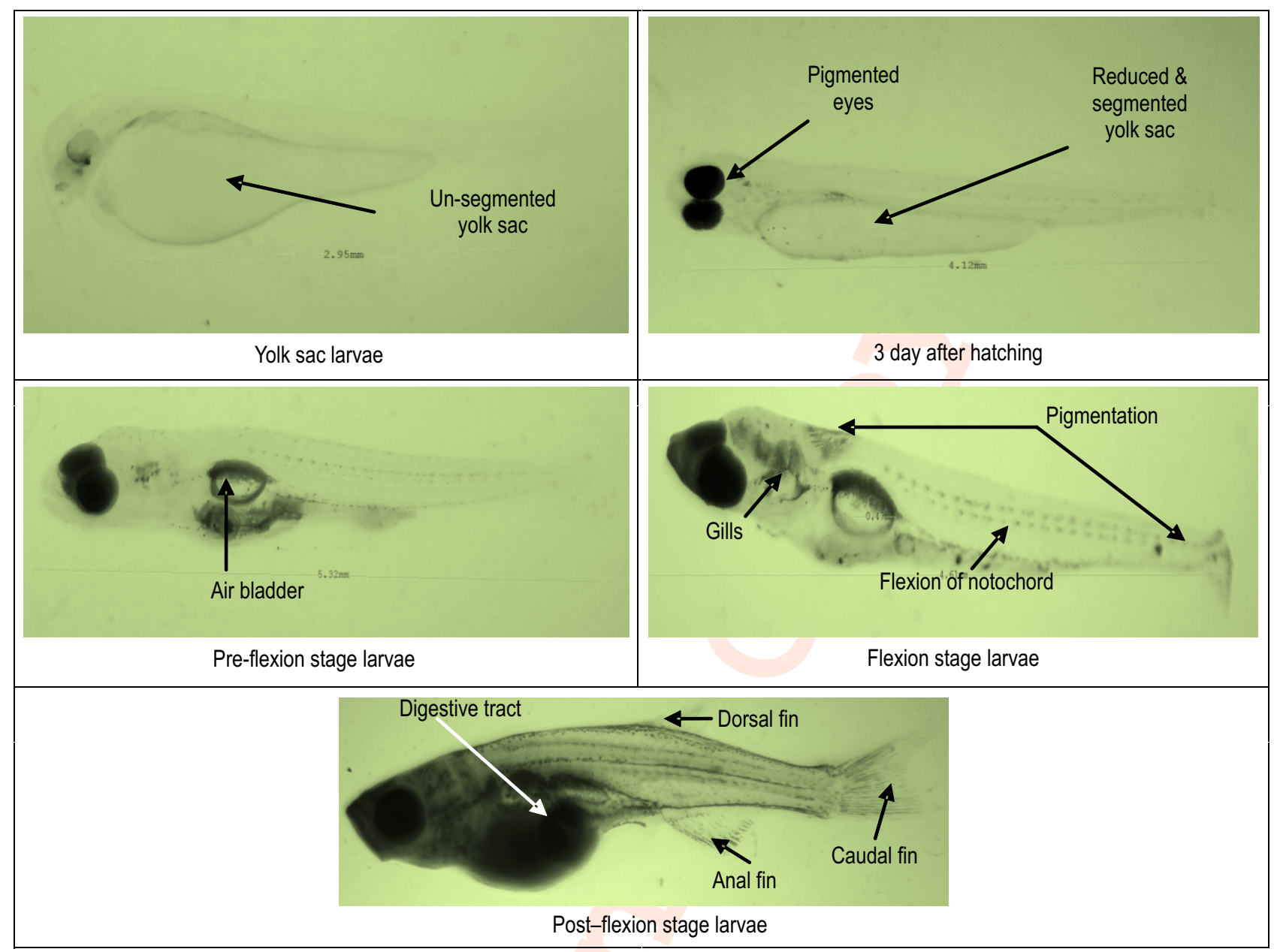

Fig. 2: Larval developmental stages: Yolk sac, pre-flexion, flexion and post-flexionlarval stages of S. denisonii observed under the trinocularmicroscope.

induced with $0.5 \mathrm{ml} \mathrm{kg}{ }^{-1}$ WOVA-FH in females. In case of, $S$. denisonii better artificial fertilization and hatching rate was obtained at $0.5 \mathrm{ml} \mathrm{kg}^{-1}$ for female and half dose for males with all the hormones which can be compared with the results reported by Mercy et al. (2015) in which breeding was successful using Ovaprim@0.4 ml kg-1 b.wt.

Egg and embryonic development of $S$. denisonii recorded by trinocular microscope is presented in detail in Fig. 1. The embryonic period was estimated from the time when as eggs were fertilized and ended until the eggs hatched out as larvae (Mollah et al., 2011). The eggs of $S$. denisonii were small, bead like having the size of $0.89 \mathrm{~mm}$ in diameter. The fertilised eggs (Fig. 1.1) were transparent with orange brown colour, whereas unfertilized eggs were opaque in pigmentation. The eggs released were sticky in nature and attached to the bottom of hatching tank. Development initiated immediately after fertilisation and activated the cytoplasmic movements. As yolk free cytoplasm moves towards the animal pole, blastodisc seperates it from the vegetal pole 10 min after fertilization (Fig.
1.2). Cell division was initiated by the formation of two blastomeres from the blastodisc (Fig. 1.3) after $20 \mathrm{~min}$ of fertilization followed by four (Fig. 1.4), eight (Fig. 1.5), sixteen (Fig. 1.6) and thirty two cell (Fig. 1.1) stage by cleavage at 0.45 , $1.05,1.25$ and $2.00 \mathrm{hrs}$ of post fertilization. Cell division continued rapidly, morula (Fig. 1.8) and blastula (Fig. 1.9) stage occurred 3.10 and $3.55 \mathrm{hr}$ after the fertilization. After $5.30 \mathrm{hr}$ of fertilization, development of blastoderm was observed. Dome shape was observed after $5.30 \mathrm{hr}$ of fertilization (Fig. 1.10). At gastrula stage, three primary germ layers were formed due to extensive cell movements (Fig. 1.11, 1.12). Blastopore (Fig. 1.14) and yolk plug stage (Fig. 1.15) development were observed after $8.25 \mathrm{hr}$ and $9.10 \mathrm{hr}$ of fertilization. Development of somites initiated after $12 \mathrm{hr}$ of fertilization and continued till hatching (Fig. 1.11 to 1.25). Head and tail clearly were visible after $14.15 \mathrm{hr}$ (Fig.1.20) of fertilization. Lens formation initiated and tail bud started separating from the yolk sac at $20.42 \mathrm{hr}$ (Fig. 1.21) post fertilization. Exactly $24.00 \mathrm{hr}$ after fertilization, heartbeat in the developing embryo began. Head and tail of the embryo differentiation was clearly noted after $25.50 \mathrm{hrs}$ (Fig. 1.23) post fertilization. Twitching movement of the 
embryo initiated after 23 hrs but vigorous twitching of the embryo was observed after $28 \mathrm{hr}$ (Fig. 1.24) post fertilization, At this phase, tail bud became longer and rudiments of primary organs became visible. Following this, after $1 \mathrm{~h}$ circulation began at 29.10 hr post fertilization. Embryo started to twist or rotate completely inside the egg membrane at the period, $30.30 \mathrm{hr}$ post fertilization.

At $31.00 \mathrm{hr}$ post fertilization twitching and lashing of the embryo inside the egg capsule became rapid. Embryo wriggled out of the egg shell (Fig. 1.25) and hatched into hatchling, 34 hrs after fertilization. The results were found slightly faster than previous report by Mercy et al. (2015). The present study used the larger size and healthy brood stock which might be the reason for early hatching. Optimum water quality parameters are conducive for the hatching process (Laurila et al., 1981). Water quality parameters such as temperature $\left(23-26^{\circ} \mathrm{C}\right), \mathrm{pH}(6.8-7.0)$, TDS (40-5. mg l-1), alkalinity (50-55 $\left.\mathrm{mg} \mathrm{l}^{-1}\right)$, hardness (80-100 $\left.\mathrm{mg} \mathrm{l}^{-1}\right)$, and dissolved oxygen (5-6.5 $\mathrm{mg} \mathrm{l}^{-1}$ ) were observed in optimum range and acted favourable for hatching process.

Newly hatched S. denisonii larva was $1.19 \mathrm{~mm}$ long (Fig. 2). Larvae were transparent with un-segmented yolk sac. Larvae head was pointed forward and distinct from the yolk. At hatching, the digestive tract appeared as a straight undifferentiated tube attached dorsally to the yolk sac. Three days after hatching, yolk sac was reduced and development dorsal fin was initiated. Dark pigment was observed in the eyes. Gradually, dark pigmentation in the eyes increased. After 4 days of hatching, opening of mouth was initiated. During this period, notochord was observed to be straight. After 4 days of hatching, (Lecito-exotrophic period) complete absorption of yolk sac was observed. Eyes were pigmented and functional. Complete opening of mouth took place during this period.

Larvae were ready for exogenous feeding. Gill rudimentary buds development initiated. During pre-flexion larva (exo-trophic period) stage, the swim bladder was developing and filled with air 5 days after hatching. Thirteen days after hatching caudal fin rays appeared. Head, body and fins were heavily pigmented over the body. Gills developed with the gill filaments. Twenty one days after hatching in the flexion larva, small pelvic fins were visible along with the well developed digestive system with accessory organs and circulatory system with gill arches. These results corroborates with the results of Mercy et al. (2015) in S. denisonii. During post-flexion stage, 22-32 days after hatching, caudal and dorsal fins were separated and developed prominently. All fin rays were formed. Well developed circulatory, digestive and initiation of reproductive organ development was observed. The egg, embryonic and larval development were similar to other teleosts (Van Snik et al., 1997; Gisbert, 1999; Gisbert et al., 2002). The present study successfully developed the breeding technology for endemic ornamental fish Sahyadria denisonii which would help to introduce hatchery-bred seeds of valuable indigenous fish in the ornamental fish trade, reduce the exploitation pressure on natural resources to a considerable level and contribute in the conservation of natural resources.

\section{Acknowledgments}

The authors acknowledge timely support and guidance rendered by the Vice Chancellor, Tamil Nadu Dr. J. Jayalalithaa Fisheries University, Dean and Faculty of Dr. M. G. R. Fisheries College and Research Institute, Ponneri, Tamil Nadu.

\section{References}

Basavaraja, N., N.N. Biswal and K. Paubiaklun: Captive brood-stock development, induced breeding, histology and nursery rearing of olive barb, Puntius sarana (hamilton). J. Aquacult. Tropics, 29, 155-169 (2014).

Behera, B.K., P. Das, N.S. Singh and A.K. Sahu: Captive breeding of an endemic medium carp Pengba, Osteobrama belangeri (Val.) with Wova-FH in Manipur. J. Aquac., 18, 23-29 (2010).

Billiard, R., K. Bieniarz, R.E. Peter, M. Sokolowska and C.Weil: Effect of LHRH and LHRH-a on plasma GtH levels and maturation/ ovulation in common carp, Cyprinus carpio kept under various environmental conditions. Aquacul., 41, 245-254 (1984).

Das, P., B.K. Beherab, D.K. Meenaa, S.K. Singh, S.C. Mandalc, S. Sahoo Das, A.K. Yadav and B.K. Bhattacharjya: Comparative efficacy of different inducing agents on breeding performance of a near threatened cyprinid Osteobrama belangeri in captivity. Aquaculture Reports, 4, 118-182 (2016).

Gisbert, E.: Early development and allometric growth patterns in Siberian sturgeon and their ecological significance. J. Fish Biol., 54, 852862 (1999).

Gisbert, E., G. Merino, J.B. Muguet, D. Bush, R.H. Piedrahita and D.E. Conklin: Morphological development and allometric growth patterns in hatchery-reared California halibut larvae. J. Fish Biol., 61, 1217-1229 (2002).

Kurup, B.M., K.V. Radhakrishnan and T.G. Manojkumar: Biodiversity status of fishes inhabiting rivers of Kerala (S. India) with special reference to endemism, threats and conservation measures. In: Proceedings of $2^{\text {nd }}$ Large Rivers Symposium (LARS2) (Eds.: R.L. Welcome \& T. Petr). Mekong River Commission and Food and Agricultural Organization, pp. 163-182 (2004).

Laurila, S., J. Piironen and I.J. Holopainen: Notes on egg development and larval and juvenile growth of crucian carp Carassius auratus. Ann. Zool. Fennici., 24, 315-321 (1981).

Mahapatra, B.K.: Breeding and rearing of indigenous ornamental barbs Puntius shanynius and Puntius sophore of NE India. In: Proceeding of Golden jubilee National Seminar on Diversification of Aquaculture Through Locally Available Fish Species, pp. 92-94 (2010).

Menon, A.G.K., K. Rema devi and M.P. Thobias: Puntius chalakkudiensis, a new colourful species of Puntius (Family: Cyprinidae) fish from Kerala, South India. Records of the Zoological Survey of India, 91, 61-64 (1999).

Mercy, T.V.A., V. Malika and S. Sajan: Breakthrough in breeding of Puntius denisonii. INFOFISH, 3, 13-11 (2010)

Mercy, T.V., S. Sajan and V. Malika: Captive breeding and developmental biology of Sahyadria denisonii (Day 1865) (Cyprinidae), an endangered fish of the Western Ghats, India. Indian J. Fish., 62, 19-28 (2015).

Mercy, T.V.A., V. Malika, S. Sajan and S. Sahayak: Distribution, reproductive biology and development of captive breeding technology of Puntius denisonii- an indigenous ornamental fish of 
the Western Ghats of India. Presented in the International Conference on Ind-Aquaria, Marine Products Export Development Authority at Calcutta, West Bengal (2009).

Mollah, M.F.A., K. Taslima, H. Rashid, Z. Hossain, M.N. Sarowar and M.R.K. Khan: Embryonic and larval development of critically endangered riverine catfish Rita rita. Eurasia J. Biosci., 5,110-118(2011).

Motilan, Y., Y. Bedajit and W. Sunitibala: Captive breeding of endangered Barbs Pethia manipurensis by oral delivery of gonadotropic signaling molecular analogue WOVA-FH. IJSRP, 4, 1-4 (2014).

Padmakumar, K.G., L. Bindu, P.S. Sreerekha, J. Nitta, A. Krishnan and P.S. Manu: First report on captive breeding of endemic red tailed silver shark Gonoproktopterus curmuca (Cyprinidae: HamiltonBuchanan 1807). IJFAS, 4, 156-160 (2014).

Peter, R.E., R. Sokolowska and C.S. Nahorniak: Comparison of (D-Arg 6. Trap 1, Leu 8, Pro 9 Net) luteinising hormone (LHRA) in combination with pimozide, instimulating gonadotropin release and ovulation in the gold fish Carrassius auratus. Canadian $\mathrm{J}$. Zool., 65, 981-991 (1986).

Prasad, G., A. Ali and K.R. Raghavan: Threatened fishes of the world. Puntius denisonii Day (Cyprinidae). Environ. Biol. Fish., 83, 189190 (2008).

Raghavan, R., G. Prasad, A. Ali, B. Pereira and L. Sujarittanonta: Damsel in distress, The tale of Miss Kerala, Puntius denisonii (Day), an endemic and endangered cyprinid of Western Ghats biodiversity hotspot (South India). Aquatic Conservation: Marine and FreshwaterEcosystems, 19, 67-74 (2009).

Raghavan, R.: Fish Conservation in Kerala. (Eds. A. Benziger and L. Sonnenschein). World Aquariums and Oceans Federation, St. Louis, USA(2010).

Rath, S.C., S.K. Sarkar, S.D. Gupta and N. Sarangi: Comparative account of induced breeding of Indian major carps with ovaprim, ovatide, wova- FH and carp pituitary extract. Indian J. Ani. Sci., 11, 1051-1060 (2001).
Routray, P., D.K. Verma, S.K. Sarkar and N. Sarangi: Recent advances in carp see dproduction and milt cryopreservation. Fish. Physiol. Biochem., 33, 413-421 (2001).

Seema, L., R.K. Krishan and S. Jyoti: Effect of ovatide hormone in oocyte maturation in sexually immature Puntius sophore a freshwater cyprinid. IJSRP, 3, 1-4 (2013).

Shaji, C.P., P.S. Easa and A. Gopalakrishnan: Freshwater fish diversity of Western Ghats. In: Endemic Fish Diversity of Western Ghats. NBFGR-NATP Publication (Eds. A.G. Ponniah and A. Gopalakrishnan). National Bureau of Fish Genetic Resources, Lucknow, India, 341pp (2000).

Siddhwartha, K.B., N. Gupta, M.M. Haque and R. Amin: Embryonic and larval development of silver barb (Barbodes gonionotus) in a mobile hatchery under laboratory condition. ESJ, Special Edition, 3,258-270 (2014).

Silas, E.G., A. Gopalakrishnan, A. Ramachandran, A. Mercy and T.V. Kripan Sarkar, Pushpangathan, K.R. Anil, R.P. Kumar, M.K. Mohan and K.K. Anikuttan: Guidelines for Green Certification of Freshwater Ornamental Fish. The Marine Products Development Authority, Kochi (2011).

Suhair, K. and S. Kumar.: A Hand Book on Induced Breeding Technology and larval Rearing of Ornamental fish 'Miss Kerala' Sahyadria denisonii (Day, 1865). Department of Fisheries, Kerala (2015).

Sundarabarathy, T.V., U. Edirisinghe and C.M.B. Dematawewa: Captive breeding and rearing of fry and juveniles of cherry barb (Puntius titteya Deraniyagala), a highly threatened endemic fish species in Sri Lanka. Trop. Agricul. Res., 16, 137-149 (2004).

Udit, U.K., A.K. Reddy, P. Kumar, M.A. Rather, R. Das and D.K. Singh: Induced breeding, embryonic and larval development of critically endangered fish Puntius sarana (Hamilton, 1822) under captive condition. J. Anim. Plant Sci., 24, 159-166 (2014).

Van Snik, G.M.J., J.G.M. Van den Boogaart and J.W.M. Osse: Larval growth patterns in Cyprinus carpio and Clarias gariepinus with attention to the fanfold. J. Fish Biol., 50, 1339-1352 (1997). 